\title{
O intelectual no "campo" cultural francês Do "Caso Dreyfus" aos tempos atuais"
}

\section{The French "cultural" intellectual}

From the "Dreyfus affair" to nowadays

\author{
HELENICE RODRIGUES \\ Dept. de História/ UFPR \\ Campus Centro, Av. XV de Novembro, 1299, 80060000 - Curitiba, PR, Brasil \\ helenrod2@yahoo.fr
}

\begin{abstract}
RESUMO Pretendendo encarnar a figura universal desse modelo, o intelectual francês se impôs, desde o final do século XIX, como uma referência conceitual e moral. Partindo do momento em que o substantivo "intelectual" integra à língua francesa, por ocasião do caso Dreyfus, esse artigo tenta restituir a genealogia desse conceito, mostrando a sua intrínseca relação com a história e a ideologia em vigor. Como se verá, a noção do intelectual, de origem essencialmente francesa, tem um caráter polimorfo. O conceito muda de acepção segundo a evolução mesma da sociedade francesa e da História, assim como diferentes épocas forjam modelos distintos de representação do intelectual. Diretamente relacionada à idéia de uma missão - a defesa da verdade e da justiça —, os intelectuais franceses, até o final dos anos 1970, enfrentam os dilemas inerentes à ambigüidade mesma da sua função: crítica e utópica. As inflexões históricas e epistemológicas dessas últimas três décadas, incidindo sobre as maneiras de agir e de pensar, rompem, definitivamente, com a representação do intelectual enquanto "maître à penser" e "pro-
\end{abstract}

Artigo recebido em22/11/2004. Autor convidado. 
feta político". Abandonando a política e o espaço público, o intelectual, re-convertido à sua nova função de "especialista", se confina nas institucionais de produção de conhecimento.

Palavras-chave História, História Cultural, Caso Dreyfus

ABSTRACT Intending to embody the universal figure of this model, the French intellectuals imposed themselves, from the end of the nineteenth century, as a conceptual and moral reference. Beginning at the moment when the noun "intellectual" became a part of the French language on the occasion of the Dreyfus case, this article attempts to recover the genealogy of this concept, showing its intrinsic relation to the current history and ideology. As will be seen, the notion of the intellectual, of essentially French origin, has a polymorphjc character. The concept changes meaning according to the evolution of French society and of History, so that different periods forged distinct models of representation of the intellectual. Directly related to the idea of a mission - defense of the truth and of justice French intellectuals, up to the end of the 1970s, confronted the dilemmas inherent in the ambiguity of their function: critical and utopian. The historical and epistemological inflections of these last three decades, including ways of acting and thinking, break definitively with the representation of the intellectual as "maître à penser" and "political prophet." Abandoning politics and the public space, intellectuals, reconverted into their new function of "specialist", are confined to the institutions that produce knowledge.

Key words History, Cultural History, Dreyfus affair

"O intelectual, escreve Sartre, é alguém que se intromete naquilo que não the diz respeito e que pretende contestar o conjunto das verdades existentes e as condutas inspiradas nessas verdades, em nome de uma concepção global do homem e da sociedade". ${ }^{1}$

Embora sumária, essa definição nos parece pertinente na medida em que ela se aplica à representação social do intelectual francês no pós-guerra, ou seja, à figura do intelectual engajado, aquele que, de 1945 a 1980, reivindicando moral e política, se investe no espaço publico.

Convém, previamente, assinalar que a noção do intelectual (o substantivo surge na língua francesa no final do século XIX, com o "caso

1 SARTRE, Jean-Paul. Playdoyer pour l-intellectuel. Paris, Gallimard, 1972, p.9. (tradução nossa). 
Dreyfus"), essencialmente francesa, tem, em suma, um caráter polimorfo. Toda tentativa de definição desse conceito que muda de acepção segundo a evolução mesma da sociedade francesa e da História parece problemática. Como veremos, mais abaixo, as diferentes épocas forjam modelos distintos de representação do intelectual.

A idéia do intelectual, escreve Edgar Morin, é por excelência histórica: "o intelectual emerge sobre um fundo cultural e sob uma forma de papel político-social". ${ }^{2}$ Visto desse ângulo, o termo intelectual parece significar mais um comportamento do que um conceito. Segundo a acepção, em uso até o final da década de 1970, o intelectual define-se menos em função de uma profissão - um produtor do saber e da cultura, possuindo uma certa notoriedade em sua área de conhecimento - , do que em função de seu engajamento, ou seja, de sua atuação "política" no espaço público.

Tendo se investido de uma missão: esclarecer o sentido da História, o intelectual engajado, do pós-guerra, se posiciona em momentos cruciais (guerras, descolonização, crises sociais e políticas). Em nome de uma "consciência crítica", seu discurso visa a uma necessária "moralização do mundo".

Ora, nessas últimas duas décadas, marcadas por guinadas ideológicas e mutações históricas, as certezas e as crenças desapareceram cedendo lugar ao ceticismo e a uma nova ordem mundial. Em conformidade com esses novos tempos, um outro modelo de intelectual, se opondo a toda idéia de dogmatismo, emerge ao longo dos anos 80. Com o final das grandes batalhas ideológicas, o modelo do intelectual engajado, associado igualmente a dos "maîtres à penser", encontra seu substituto ideal na figura do chamado intelectual expert. Abandonando a política e o espaço público, o intelectual, re-convertido à sua nova função de "especialista", se confina nas institucionais de produção de conhecimento.

Se o final do engajamento político assinala, no início dos anos 80, o "silêncio dos intelectuais", o abandono de uma missão revela os sinais de uma profunda crise da sociedade francesa. Frente as ameaças que pesam sobre o mundo, em geral, e a França, em particular, (racismo, violência, terrorismo), o intelectual não deveria desempenhar seu antigo papel de consciência moral? Não se trata mais, nesse momento de aceleração da Historia (globalizações, terrorismos, liderança unilateral), de uma demanda de engajamento à maneira de Sartre ou de Foucault (em defesa de um partido, de um sujeito oprimido ou de minorias culturais), mas de um novo posicionamento em relação às inquietudes do presente (defesa dos direitos humanos, ameaçados em diferentes partes do mun-

2 MORIN, Edgar. "La mission de l'intellectuel", In: L'intellectuel, l'intelligentsia et les manuels, (Belkik, org.), Paris, Antrophos, 1983, p.26. 
do e críticas ao reino do econômico, entendida, sobretudo na França, como crítica ao poderio americano).

\section{Gênese e "nascimento" do intelectual}

Sinônimo de clerc, a palavra "intelectual", na língua francesa, conota a idéia mesma do sagrado. Segundo Régis Debray, os ancestrais desses "clérigos" encarnam, desde tempos antigos, uma função sacerdotal: "a dos sacerdotes-mágicos, enunciadores da verdade sagrada, produtores/guardiões dos mitos". No final da Idade Média, com a laicidade da vida cultural, os "clérigos" leigos eruditos substituem os "clérigos" da Igreja, outrora garantes da tradição cultural. Desde então, o termo "clérigo" começa a designar "homem da cultura". "O "clérigo", escreve Debray, nasce como homem de Estado, quer dizer, que ele o queira ou não, como homem de Deus. (...) A função intelectual é imediatamente política; a função política imediatamente clerical. Deus se deduz do "clérigo", não como astúcia ou intriga mas como sua condição de possibilidade, a base ilusória de sua real potência". ${ }^{3}$

Se o poder intelectual pressupõe uma emanação do saber, podemos, então, deduzir que o "intelectual" ("sacerdote") exerce, por assim dizer, uma função de "contra-poder" na sociedade política. Desenvolveremos, mais abaixo, esse argumento.

Por sua vez, o século das Luzes forja um outro modelo de intelectual moderno, consagrado ao culto da razão. A crítica racional moderna tornase, assim, a condição suprema da possibilidade do pensamento intelectual, a ponto de transformar a razão em uma nova religião, ou até mesmo em um mito. "Verdade e Razão" se constituem em uma só e única realidade

O escritor - jurista da idade clássica (utilizando a expressão de Michel Foucault), cuja encarnação mais expressiva é Voltaire, pretendendo representar a lei de Deus ou do Estado em nome da razão universal, deve, a partir de então, denunciar as mentiras, os despotismos e as injustiças. Voltaire, Diderot e os Enciclopedistas constituem a gênese dos denominados "literatos" e/ou "pensadores" que, posteriormente, defendendo os valores universais se organizam como grupo social, no final do século XIX.

Veremos, quase dois séculos mais tarde, com o "caso Dreyfus", a reprodução de um fenômeno mais ou menos similar. A necessidade de enunciar a verdade se impõe, então, aos intelectuais engajados como um dever moral, contra a mentira pública e o erro judiciário. ${ }^{4}$

3 DEBRAY, Régis. Le scribe - gènese du politique. Paris, Grasset, 1980, 1980, p.15.

4 f. RODRIGUES DA SILVA, Helenice. Texte, action et histoire - réflexion sur le phénomène de l'engagement. Paris, L'Harmattan, 1995, p.21. 
Historicamente datado, o substantivo "intelectual" faz a sua irrupção na língua francesa no decorrer do "caso Dreyfus", ${ }^{5}$ momento em que a definição mesmo do "intelectual" é objeto de uma violenta batalha. O surgimento dessa categoria social, portanto, indissociável da luta contra o poder, configura a idéia da ação como condição mesma da existência dos "intelectuais".

O texto de Ëmile Zola, J'accuse, publicado em 1898 no jornal Aurore, denunciando os erros judiciários e o complô do exército francês contra Dreyfus, torna-se o ponto de partida de uma definição da "missão" do intelectual. Apoiando esse artigo, um manifesto, dito dos "intelectuais", fundado no direito institucional de "petição" e assinado por um número significativo de escritores, artistas, professores universitários, etc., propõe, assim, exprimir através desse ato coletivo, um protesto político. Segundo os assinantes dessa petição a revisão do processo Dreyfus, remete à exigência mesma de reatar os princípios de 1789.

Três particularidades podem ser detectadas nessa petição. A primeira: trata-se de reivindicar o direito ao escândalo, ("após todas as tentativas fracassadas dos procedimentos legais para despontar a verdade"). A segunda: reforça o direito de se agrupar para dar mais força ao protesto (afirmação de uma comunidade política e social). A terceira: autoriza o direito de reivindicar um poder simbólico (proveniente da acumulação de títulos que a maior parte dos assinantes mencionava ao lado do nome). ${ }^{6}$

Os assinantes dessa petição, que pediam aos poderes público a revisão do processo em nome da justiça e contra a razão do Estado, são ironicamente designados pelos "anti-dreyfusards" (assinantes de um contra-manifesto) "intelectuais". Num primeiro momento, essa palavra dotada de uma conotação pejorativa assimila o dreyfusard ao intelectual da esquerda, ou seja, àqueles que, exercendo cargos de pensadores e já tendo adquirido uma certa notoriedade, colocam-se a serviço da comunidade nacional.

Em nome de princípios universais: a defesa da verdade e da justiça, os "intelectuais" (os dreyfusards) reivindicam .uma participação na vida da "pólis". A intervenção pública dos "intelectuais", cuja conseqüência será a revisão do processo, garante-lhes o direito à palavra pública (le droit de Cité). Na verdade, essa intervenção intelectual reforça a posição ideológica do grupo republicano no Parlamento, frente a seus adversários nacionalistas da direita.

5 apitão de origem judia e alsaciana, Alfred Dreyfus é injustamente acusado de fornecer documentos secretos ao exército alemão. Preso em 1894, ele é julgado de maneira sumária e condenado à degradação militar e à deportação. Longe de ter sido somente um erro judiciário, o "caso Dreyfus" correspondeu a uma das maiores crises políticas da III República francesa.

6 HARLE, Christophe. Naissance des intellectuels - 1880/1890, Paris, Minuit, 1990, p.8. 
Consequentemente, é a partir do "caso Dreyfus" que serão circunscritos dois pólos de valores no pensamento intelectual francês, um sendo universalista, o outro nacionalista. Essa divisão simbólica, implicando a idéia da esquerda e da direita, marcará os combates políticos (e intelectuais) ao longo do século XX.

Ora, o neologismo "intelectual" designa, originalmente, uma vanguarda cultural e política que ousa, no final do século XIX, desafiar a razão de Estado. No entanto, essa palavra, que poderia ter desaparecido após a resolução dessa crise política, integra-se à língua francesa. Se, por uma lado, ela designa um grupo social, por outro, ela qualifica uma maneira de se conceber o mundo social, pressupondo, notadamente, uma oposição às hierarquias estabelecidas.

Em seu livro Naissance des "intellectuels -1880/1890, o historiador Christophe Charle questiona as razões pelas quais os "intelectuais" emergem (nessa época de estabilização da República e da democracia), como grupo social, como forma de percepção do mundo social e como categoria política. Segundo esse autor, para melhor compreender o paradoxo de um acontecimento que estrutura duravelmente a vida cultural e política da França, deve-se levar em conta alguns fatores ligados ao novo "campo"7 intelectual. A vontade por parte do Estado Republicano de criar novas elites culturais (abertura de concursos nacionais, criação de novas escolas), baseadas na meritocracia, possibilita a expansão e o aumento do número de professores universitários. Paralelamente, o crescimento do número de estudantes é concomitante ao aparecimento de uma espécie de "proletariado literário", expressão que desponta nas redações dos jornais da época, para designar uma vanguarda cultural. Impossibilitados de sobreviver no aspirado mundo artístico e literário, esses jovens diplomados rejeitam as representações de um modelo de referência que, na verdade, correspondia a um estado anterior da vida cultural. As modificações profundas ocorridas no "campo" intelectual o aumento do número de estudantes e o aparecimento de uma vanguarda intelectual anticonformista - criam condições favoráveis à afirmação coletiva dos "intelectuais". ${ }^{8}$

Segundo Christophe Charle, a comparação entre as duas petições: a dos "pró- Dreyfus" e a dos "contra-Dreyfus", permitem, por um lado, detectar as oposições traduzidas em termos de querelas de gerações, de estratégias de grupos universitários, de escolas literárias, etc. Por

7 De maneira simplificada, o conceito de "campo" de Bourdieu aplica-se tanto a realidades vastas (campo econômico, campo político) como à totalidade de um campo cultural (campo artístico, literário, artístico, etc.) ou a um grupo restrito (o campo editorial ou o campo de uma revista, por exemplo). Esse conceito designa o espaço social no interior do qual existem relações de força para a imposição e a definição do jogo e dos trunfos necessários para dominar esse jogo. O campo é marcado pelas relações objetivas entre posições.

HARLE, Christophe. Naissance des intellectuels - 1880/1890, Paris, Minuit, 1990, p.17. 
exemplo, os assinantes literários, assinantes da petição em favor de Dreyfus seriam mais jovens que seus adversários (anti-Dreyfus) e os universitários pertencentes à École de Chartres, ao Collège de France ou à Ëcole Pratique des Hautes Études, tenderiam a se situar mais à esquerda, do ponto de vista políitico, se comparados aos "intelectuais" de outras instituições. Ao lado de professores universitários, tais como: François Simiand e Émile Durkheim, destacam-se, nessa lista, estudantes (Charles Péguy, por exemplo), assim como escritores já consagrados (Anatole France, por exemplo) ou iniciantes (como, André Gide e Marcel Proust).

Por outro lado, os assinantes da lista oposta, na maioria católicos e, em grande parte, formados em disciplinas da antiguidade clássica e do direito, exprimiriam o perfil do intelectual da direita., ou seja, eles seriam os portadores dos valores tradicionalistas e nacionalistas.

Aproximando-se do grupo dos republicanos, a vanguarda literária e artística, através do ato da petição, passa a intervir no campo do poder, visando a contestar o próprio poder das elites dominantes. Convém lembrar que o "caso Dreyfus" reflete um clima de tensão política, que tem por pano de fundo, nesse momento, o anti-semitismo da sociedade francesa. Defendendo a razão de Estado, os militares, os políticos anti-republicanos os "intelectuais" da direita adotam, ao longo do desenrolar desse episódio, uma postura, no mínimo, ambígua. Embora admitindo a possibilidade da inocência do capitão Dreyfus, esses últimos recusam "dizer a verdade" , ou seja, revelar à opinião pública o complô do estadomaior do exército, considerando que essa revelação seria prejudicial à honra da nação e à reputação das forças armadas. Aliás, durante mais de 100 anos, a razão de estado prevaleceu sobre a verdade histórica.

Esse acontecimento político, que estrutura, duravelmente, o imaginário coletivo, vai se tornar a referência histórica, por excelência, em momentos de crise social e política da nação. O "caso Dreyfus" inaugura uma forma de protesto político, por parte das vanguardas culturais, fazendo emergir valores morais no combate político.

A concepção de militância originária do "caso Dreyfus" (ou seja, o direito de participar à esfera política da "polis"), passa a delinear a função social do intelectual. É dentro dessa perspectiva, de defesa dos direitos humanos dos colonizados e de combate contra o poder colonial, que a guerra da Argélia (1954/1962) será considerada, cinqüenta anos mais tarde, um outro "caso".

As paixões suscitadas pelo "caso Dreyfus" só podem ser entendidas se vinculadas aos rastros deixados por esse acontecimento na memória coletiva. Responsáveis pelas convulsões profundas da nação, duas forças antagônicas (nacionalismo x universalismo), que se afrontam no final do século XIX, se reproduzem na historia francesa ao longo do século 
XX. Assim, o anti-semitismo, um dos componentes do nacionalismo, constitui a própria negação dos valores universalistas, oriundos da Revolução francesa. Percebido, no final do século XIX, como uma "tara nacional", o anti-semitismo ressurge, inesperadamente, no período da Ocupação alemã, entre 1940/44, precipitando novamente o país em um novo traumatismo. Percebido como uma fratura moral da sociedade francesa, o "caso Dreyfus", divide a França do ponto de vista de seus valores. Paradoxalmente, se esse episodio desonra a pátria dos direitos humanos, ele salva a honra da nação graças à mobilização dos "intelectuais", transformando-se, posteriormente, em uma espécie de paradigma da modernidade.

\section{O intelectual engajado e a enunciação da "verdade"}

Embora, desde meados dos anos 1930, os intelectuais de esquerda se mobilizam contra o fascismo, fundando Ligas Anti-fascistas, o engajamento politico dos intelectuais só se concretizará em uma ação efetiva no espaço público, no pós-guerra.

Diante da derrota dos valores da direita, o "campo" intelectual francês do pós-guerra se re-estrutura à esquerda, no interior do qual os intelectuais, comunistas e/ou simpatizantes da URSS (progressistas) passam a ocupar uma posição dominante.

Ora, o modelo tradicional do intelectual "legítimo" do pós-guerra, encarnado por Sartre, pressupõe uma participação na Historia, ou seja, o engajamento político deve se traduzir por uma ação concreta. Em razão mesmo de suas concepções proféticas sobre o futuro, fundadas na crença do "progresso da história", os intelectuais engajados, no imediato pós-guerra, são designados, igualmente, "intelectuais proféticos". A missão atribuída ao intelectual é, conseqüentemente, a defesa dos princípios tidos por universais. De acordo com esses princípios, as noções de justiça e de verdade, oriundas da Declaração dos Direitos Humanos (1789), devem se aplicar a todos os indivíduos.

A figura dominante do intelectual engajado do pós-guerra "responde a uma dupla definição por ele mesmo e pelos demais", afirma Edgar Morin. Em outras palavras, o intelectual se define não tanto pela sua participação a um grupo sócio-profissional mas, sobretudo, pela sua relação à cultura de seu tempo, ou seja, pela sua relação ao universo mental e político de um momento histórico. Produto dos acontecimentos históricos recentes, essa cultura intelectual se fundamenta nos valores progressistas.

Edgar Morin mostra bem, que "a qualidade do intelectual não está necessariamente ligada à sua participação à intelligentsia, mas "ao uso 
da profissão por e pelas idéias". ${ }^{9}$ Em outras palavras, o intelectual é percebido ou tido como tal, a partir do momento em que ele engaja sua autoridade, já reconhecida, em favor de uma causa moral, por via de um ato político. Petições, assinaturas, manifestos autenticam a "marca" do intelectual cuja função primordial pressupõe a crítica social.

Consequentemente, a atividade do intelectual engajado, para não dizer sua própria existência, é conflituosa e ambivalente. Se, por um lado, ele tem por função produzir conhecimentos e formular idéias, por outro, investido por essas mesmas idéias, ele tende a "enunciar a verdade". A prática do intelectual situa-se, então, entre dois pólos distintos e contraditórios: a produção do saber e a enunciação da verdade. A tentação ideológica ameaça os intelectuais a partir do momento em que eles consideram o saber como uma ideologia e esta última como uma "verdade".

"Os intelectuais, afirma Edgar Morin, só percebem, neles mesmos, a função crítica, não se dando, muitas vezes conta, que eles são os principais produtores ou formuladores das ideologias, ou seja, de mitos, que eles próprios pretendem criticá-los". ${ }^{10}$ Se, por um lado, ele têm por dever a crítica permanente de mitos e das ideologias, por outro lado, elaborando essa propria crítica, eles reproduzem, igualmente, mitos.

Ao lado da função cognitiva de organização do pensamento e da transmissão do conhecimento, encontramos no discurso dos intelectuais dessa época a função ideológica, que tem por finalidade explicar o mundo e fundar um discurso da verdade. ${ }^{11}$ Com efeito, a idéia da "verdade" não estaria diretamente ligada à função do "profetismo" atribuída ao intelectual engajado (particularmente aos existencialistas) do pósguerra?

Em seu livro Autocritique, Edgar Morin já questionava o critério atribuído à palavra "verdade". "Qual é, indaga o autor, esse sentimento inverificável segundo o qual a verdade é superior à mentira (sentimento aliás, tão forte, na cegueira como na lucidez), senão o fetichismo da verdade?". ${ }^{12}$

A critica feita pelos próprios intelectuais, no final do século XX, remetem às analises feitas por Edgar Morin em sua "autocritica", de 1959. A abnegação dos principois morais em detrimento das paixões politicas não teria sido uma constância na história dos intelectuais franceses?.

Pelo momento, trataremos da questão da verdade, como sendo equivalente ao oposto da mentira, noção que corresponde à enunciação: "em função da verdade" ("pour la vérité"). Na verdade, o discurso intelectual do pós-guerra é pontuado pela referência a essa palavra fetiche.

9 ORIN, Edgar, op.cit., p.18.

10 MORIN, Edgar. Autocratique, Paris, Julliard, 1959, p.60.

11 Cf. H. SILVA, Rodrigues da, op.cit., p.20.

12 MORIN, Edgar, Autocritique, p.252. 
De onde vem essa pretensão dos intelectuais de pretenderem, através de discursos, desvendar a verdade do mundo?

No momento do engajamento dos intelectuais contra a guerra da Argélia, a palavra "verdade" torna-se um dos componentes de seus combates. "Sou uma intelectual, escreve Simone de Beauvoir, e concebo uma importância central à palavra e à verdade". ${ }^{13}$

"Dizer a verdade sobre o regime colonial na Argélia, lutar para cessar a tortura, combater o racismo, eis as obrigações que se impõem a todos os intelectuais". ${ }^{14}$

A busca de uma verdade, entendida num sentido histórico e ideológico, torna-se uma constância no discurso dos intelectuais contra a guerra da Argélia (1954/1962). Em plena era da descolonização, opondo-se à marcha da História, a França luta para guardar essa colônia. "Contra uma imprensa que condiciona a opinião pública, anunciando que a Argélia é a França, contra as mentiras pronunciadas pelos políticos sobre a pacificação na Argélia", ${ }^{15}$ a verdade torna-se, na perspectiva dos intelectuais engajados, uma necessidade, um imperativo, um dever moral. Nesse caso específico, a noção da "verdade" apresenta-se, sobretudo, como equivalente ao "dizer verdadeiro" (o dire vrai). Trata-se aqui de uma verdade no sentido histórico do termo, o que equivale a um efeito do conhecimento, à elaboração de uma informação correta. A ignorância da grande maioria da população francesa em relação ao problema colonial, por exemplo, obrigava os partidários da descolonização a exercer uma ação pedagógica, voltada para uma informação verídica. (o parler-vrai). Assim, nos discursos dos intelectuais, o "falar verdadeiro" corresponde a um ato da verdade.

Voltaremos a falar sobre a questão da "verdade" mas, pelo momento, examinaremos o fenômeno do engajamento, nova prática cultural que determinará o comportamento dos intelectuais (de esquerda e engajado) ao longo de três décadas do pós-guerra. .

\section{"Falar é agir": a noção do engajamento}

A tomada de consciência da barbárie do nazismo acentua, junto aos intelectuais franceses, o sentimento de contingência, de precariedade e do absurdo da existência. A Segunda Guerra mundial torna-se, portanto, o ponto de partida para um questionamento das tragédias da História. Em decorrência do sentimento de culpabilidade (a impotência frente ao nazismo), ressentida por grande parte dos intelectuais, no imediato pós-

13 BEAUVOIR, Simone de. La force des choses. Paris, Gallimard, 1963, p.387.

14 BOURRICAUD, François. Le bricolage idéologique- essai sur les intellectuels et les passions démocratiques, Paris, PUF, 1980, p.179.

15 BEAUVOIR, Simone de, op.cit., p.387. 
guerra, uma outra maneira de se situar no seu tempo e de se posicionar no mundo é, então, reivindicada como forma (schème) intelectual dominante: o engajamento político.

Se Auschwitz já havia revelado a barbárie da humanidade, por sua vez, as "virtudes" do comunismo, legitimadas pela sua vitória sobre o nazismo, reforçam o advento de um novo "profetismo" intelectual: o comunismo transforma-se, na opinião de Sartre, em "horizonte que não pode ser ultrapassado".

A propósito, o sucesso que conhece o existencialismo nesses anos de pós-guerra pode se explicar de maneira concomitante pela perda de significação objetiva do mundo (a "essência") e pela consciência do "despropósito da existência" (o absurdo). A primazia da existência em relação à essência, a primeira precedendo a segunda constitui o fundamento mesmo dessa filosofia..

Se, como afirma Adorno, após Auschwitz não se pode mais pensar como antes, o constato mesmo da derrota da razão impõe uma nova visão de mundo e, conseqüentemente, uma necessidade imperativa de engajamento contra a barbárie. O moralismo de outrora é substituído por uma práxis coletiva: o engajamento que pretende eliminar a distância entre o pensamento e a ação. Ora, a pressão exercida pela política sobre a cultura, tendo por resultado o engajamento, obriga o intelectual a escrutar todas as conseqüências políticas de suas escolhas filosóficas, como a fundar filosoficamente suas escolhas políticas. ${ }^{16}$

Revestidos de uma "condição" de políticos, produtores ou consumidores de ideologia, os intelectuais se definem, nos primeiros anos do pós-guerra, em relação ao comunismo; ora a serviço do partido (os "intelectuais orgânicos"), ora em sua periferia: os chamados "compagnons de route" (os companheiros de trajetos). Convém lembrar que, a vitória da URSS frente ao nazismo e o triunfo inelutável do Partido Comunista Francês no pós-guerra, reforçam a idéia da missão histórica do proletariado, como classe universal e motor da História. Assim, o filósofo e/ou o intelectual engajado atribuem aos sujeitos oprimidos (proletariado, colonizado, minorias éticas e culturais) a tarefa de restituirem um sentido à História..

Para uma maioria dos intelectuais, nos primeiros anos do pós-guerra, sobretudo, para os existencialistas, o drama de seus respectivos engajamentos explica-se através de um profundo conflito de consciência. Se, por um lado, para eles, o proletariado - "valor ético absoluto" e objeto de opressão - inspira-lhes um certo fascínio, por outro lado, o

16 Texto original: "Sociology and philosophy in France since 1945"; Social Research, n. 24, spring 1967, citado por POLLACK, Mikael, "La planification des sciences sociales"; Actes de la Recherche en Sciences Sociales, 1976, n. 2/3, p.110. 
sistema representa uma ameaça. A esse propósito, a frase de Sartre, em "Materialismo e Revolução"17 traduz bem essa dupla tensão: "estaria diante de um dilema inaceitável: trair o proletariado para servir a verdade ou trair a verdade para salvar o proletariado?". ${ }^{18}$

Retomando a linhagem dos revolucionários europeus do século XIX, os intelectuais engajados atribuem, inicialmente ao proletariado, e, em seguida aos colonizados, uma função profética de agentes históricos das transformações. Variante do engajamento, o profetismo intelectual torna-se portador de uma utopia revolucionária. Nesse exemplo preciso, a alusão ao profetismo bíblico remete ao mito revolucionário, na sua leitura ideológica e utópica da História.

"Dentro da nossa memória filosófica, dirá Althusser, essa época permanece a [era] dos intelectuais armados, combatendo o erro em todos os covis, época dos filósofos, sem obra, como no nosso caso, mas que fazíamos política de toda obra e, resolvíamos e dividíamos as dificuldades do mundo, utilizando uma só lâmina: artes, literaturas, filosofias e ciências, através da cruel divisão das classes. Esse era o tempo que, caricaturalmente, uma palavra resume ainda, bandeira flutuando no vazio: ciência burguesa, ciência proletária". ${ }^{19}$

Embora o engajamento não representasse uma noção nova, ${ }^{20}$ foi somente no final de 1945 que, Sartre publica o manifesto sobre o engajamento dos escritores, no promeiro numero da revista Les Temps Modernes (outubro de 1945). As bases da literatura engajada serão retomadas e sistematizadas em Qu'est-ce que la littérature? (Que é a literatura,?; 1947).

Uma leitura superficial desse texto, onde serão expostas as bases do existencialismo, revela algumas idéias fortes. Inicialmente, Sartre critica a "tentação da irresponsabilidade" dos escritores de origem burguesa. Segue-se, então, uma primeira constatação: toda escrita tem um sentido e o escritor escreve para dizer alguma coisa. "Para nós, declara Sartre, com efeito, o escritor não é Vestal nem Ariel, embora não o queira, ele está "no mundo real". Conseqüentemente, ele não pode escapar a seu tempo. Definindo o papel do escritor e o lugar da literatura como sendo o "espelho do nosso tempo", Sartre declara que: "não se trata de escolher sua época mas de se escolher dentro dela. (...) O escritor está em situação na sua época, cada palavra [pronunciada] tem ressonân-

17 Artigo publicado, originalmente, em 1946, na revista Les Temps Modernes, ele é re-publicado em Situations III, Gallimard, 1949.

18 SARTRE, J.P., « Matérialisme et Révolution », In : Les Temps Modernes, 1949, p.172.

19 Citação de LEEENHARDT, Jacques et MAY, Barnaba. La force des mots - le rôle des intellectuels, Paris, Megrelis, 1981, p.124.

20 Nos anos 30, em razão da ascensão do movimento autoritário e da criação de Ligas Fascistas, na França, os intelectuais de esquerda fundam um "comitê de vigilância anti-fascista", prenunciando um engajamento político no espaço público. 
cia, cada silêncio também". A partir dessa premissa, Sartre deduz: "já que nós agimos sobre o nosso tempo pela nossa própria existência, nós decidimos que nossa ação será voluntária". Nessa perspectiva ontológica, o engajamento é objeto de uma escolha individual. ${ }^{21}$

Outra premissa enunciada nesse texto diz respeito à finalidade da ação: "nossa intenção é contribuir a produzir certas modificações na sociedade que nos cerca". Em suma, esse manifesto propõe reabilitar a concepção do "homem total", "totalmente engajado e totalmente livre".

Na teoria da literatura engajada proposta por Sartre, a pena se assemelha a uma espada, em vista de uma mudança radical. A relação do escritor com a sua obra, entendida como uma critica social, pode ser definida através do axioma: "falar é agir".

Vale lembrar que a geração de Sartre, profundamente marcada pela filosofia de Hegel, Husserl e Heidegger, reivindica, em relação ao idealismo abstrato, uma filosofia concreta: o existencialismo. Nessa busca de um contato com o real, Sartre faz da práxis a essência mesma da doutrina da ação. Agir para mudar, fazer a "oposição dentro da oposição" contra toda idéia abstrata, isso seria, em suma, o projeto dos existencialistas. Mas, a ação sendo de uma certa maneira "indeterminada", ela poderia conduzir a uma apologia "abstrata" da ação pela ação, sem horizontes escatológicos e à tomada de posições contraditárias.

Essa dificuldade de ultrapassar o pensamento pela ação (ação que, muitas vezes, se confunde com um projeto revolucionário), constitui uma das problemáticas maiores da obra filosófica de Sartre. O essencial no seu pensamento consiste, então, na idéia de resistir, e a jamais se comprometer com o que Max Weber chama de "ética de responsabilidade", base de sua doutrina do engajamento. A contestação, da mesma maneira que a auto-contestação assume, assim, um papel fundamental em seus escritos políticos. Esse privilégio crítico e essa reação às instituições e à ordem estabelecida, percebidos por Sartre, como um "mal absoluto", foram reivindicados, em nome de uma moral fundada na liberdade.

Na pessoa de Sartre encarna-se, assim, a figura do intelectual engajado e do "intelectual total", símbolo, no pós-guerra, do tempo das consciências universais.

\section{Do "intelectual total" ao "intelectual dissidente"}

Na perspectiva sartriana, o engajamento político é fruto de uma escolha individual. Mas, como se concilia liberdade individual e "verdade" universal?

21 SARTRE, J.P. «Le Manifeste », In : Les Temps Modernes, 1945, p.3, 4. 
Os intelectuais da esquerda não comunista buscam na sociedade do pós-guerra uma posição suficientemente engajada para que a universalidade de seus discursos apareça como equivalente ao discurso da própria História. Se as filosofias da história (hegelianismo e marxismo) pretendiam dar um sentido à História, esses dois modelos de sínteses gerais concebiam a idéia de progresso como o movimento mesmo da História. Ora, Sartre define a História como "a lógica viva da ação"; toda posição política correspondia, portanto, a concretização dessa ação. O engajamento responderia, desse modo, a uma situação histórica imediata e conjuntural: a Resistência, a guerra fria, as guerras coloniais, por exemplo. O intelectual engajado poderia, então, se definir a partir de sua posição crítica em relação ao mundo, afirmando-se como o representante das forças progressivas e como o defensor de uma causa humanitária.

Convém, no entanto, precisar que a doutrina do engajamento, exposta por Sartre em 1945/46, reflete ainda sua fase um tanto "idealista", exprimida no L'être et le néant ( $O$ ser e o nada). Sartre concebe a ação em termos unicamente individuais mas, que se inscrevem na História. Nesse momento preciso, suas divergências ideológicas com o marxismo, o levam a considerá-lo: "metafísico, dissimulado em forma de positivismo". Na verdade, nos primeiros anos do pós-guerra, o marxismo ocupa um espaço relativamente reduzido no campo filosófico francês (poucos intelectuais possuíam um sólido conhecimento das obras de Marx). Esse lacuna teorica do marxismo pode explicar os argumentos elementares utilizados por Sartre, para contestá-lo em "Materialismo e Revolução".

Ë somente a partir de 1952/53 que o postulado da ação individual na doutrina do engajamento será questionado por Sartre. A conjuntura histórica (maccartismo, a guerra na Coréia, por exemplo), ou seja, a intensificação mesmo da guerra fria, o obriga a buscar uma maior aproximação política com a URSS.

Crítico em relação à filosofia marxista da histórica, Merleau-Ponty distancia-se, nesse mesmo momento, do comunismo, rompendo as relações com Sartre e acusando suas posturas, de "ultra-bolchevistas, em As Aventuras da dialética (1955).

Mas, como se fundamenta filosoficamente a doutrina do engajamento? A fim de solucionar um problema ontológico maior do existencialismo, ou seja, a conciliação da liberdade individual com a ação política (e na impossibilidade de elaborar um tratado da moral), Sartre recorre (em "Existencialismo é um humanismo"), a um critério universal: o da verdade. Uma nova moral política é assim elaborada, a partir de um julgamento moral, definido, inicialmente, como um julgamento da verdade. As provas e as justificativas morais se justapõem, assim, às certezas históricas. 
Ora, do ponto de vista filosófico, conciliar a escolha individual com a universalidade da verdade constitui uma tarefa, no mínimo, difícil..

$\mathrm{Na}$ definição de Sartre, o intelectual engajado, enquanto mestre da verdade, teria por função ética, representar uma "consciência universal". A esse propósito, a frase de Merleau-Ponty, escrita em 1946, exprime bem essa missão auto-atribuída ao intelectual: "nós não temos muitas armas, particularmente, nós não dispomos de uma arma poderosa, nós só temos uma arma: a verdade, é essa arma que deverá ser utilizada". ${ }^{22}$

Mas, a partir de quais critérios essa "verdade" pode ser determinada? Sem dúvida, na perspectiva sartriana, a verdade é subjacente à concepção dos existencialistas (progressistas) de uma ação na História. Se a ação se realiza através de uma participação engajada à política, o papel do intelectual consiste, notadamente, no desvendamento de uma "verdade", na História.

Se os intelectuais engajados exerceram plenamente a função crítica no domínio da política, opondo-se a toda forma de poder e opressão (sobretudo no momento das guerras coloniais), eles se traíram na obediência ao dogma da Revolução. Aliás, a Traição dos Intelectuais, título de um livro, publicado em 1927 por Julien Benda, propondo modelos normativos para a ação do intelectual, já denuncia as derivas ideológicas (da direita e da esquerda) que afastam o "clérigo" de sua missão: a de serem guardiões dos valores morais.

Segundo esse autor, as críticas políticas feitas pelos intelectuais , a partir de uma causa mítica, enfraquecem a própria força do pretendido julgamento moral. Ora, durante a guerra da Argélia, a reprodução de mitos vai se operar por meio de uma transferência: o proletariado será substituído pelo colonizado, ou seja, pelo oprimido, e a URSS será substituida pelo Terceiro Mundo.

A propósito, a guerra da Argélia oferece a ocasião ideal para o engajamento efetivo dos intelectuais, a concretização da noção, até então abstrata, de engajamento se efetua através do discurso. O "logos" tornase "práxis", ou seja, o ato do discurso transforma-se na própria ação de militância.

O prefácio de Sartre no livro Condenados da Terra, de Frantz Fanon, atinge o paroxismo da literatura engajada sartriana em direção ao Outro, ou seja, em direção ao Terceiro Mundo. Aliás, esse prefácio legitima um novo tipo de discurso ideológico, o do "terceiro-mundismo". Como todo discurso ideológico, a violência se faz presente e sub-entende, na sua própria lógica argumentativa, a demonstração da "verdade". Nesse prefácio se encontram os argumentos ideológicos que, na sua grande mai-

22 Citação de COHEN-SOLAL, Annie. Sartre, Paris, Gallimard, 1983, p.389. 
oria, já tinham sido esboçados nos escritos anteriores de Sartre, mas que se revestem de um caráter mais radical. A linguagem transforma-se em lugar da violência.

Do intelectual engajado, à imagem de Sartre, ao intelectual dissidente (ou específico), encarnado por Foucault, ${ }^{23}$ a função crítica do intelectual assinala a logica do "campo" (de 1945 a 1980). Segundo esse último, entre o saber e o poder existe uma relação inerente e intrínseca... Aliás, Foucault criticou "sistematicamente [o intelectual] que se declara mestre da verdade e da justiça, [aquele] que pretende resistir aos efeitos "repressivos do poder a ele clamando sua verdade". ${ }^{24}$ Foucault denunciou, igualmente, a pretensão do discurso dos intelectuais a caráter profético e universal, insistindo sobre a idéia de que a verdade não é estranha à noção do poder. Mas, embora ele tenha se oposto ao modelo do "intelectual universal", preferindo a referência do "intelectual específico" ou "dissidente", ou seja, aquele que fala em seu próprio nome e não em nome do cidadão, do partido ou do oprimido, aquele que defende causas pontuais (como a reforma das prisões e o movimento dos homosexuais), Foucault permanece próximo do modelo do intelectual engajado à maneira de Sartre. Combinando o saber e as intervenções práticas, o intelectual dissidente ou específico, investe-se somente no seu domínio de conhecimento. Seu objetivo se limita a esclarecer os mecanismos repressivos que, segundo Foucault, de maneira dissimulada, contagiam a sociedade.

\section{O fim de um modelo e as metamorfoses intelectuais}

Indissociável de uma certa ideologia comunista, a noção de engajamento é objeto de critica e de reticências desde meados da década de 1950. As denunciações dos crimes de Stalin, durante o XX congresso do partido comunista em 1956 (em Moscou), e a insurreição em Budapeste (nesse mesmo ano), assinalam as primeiras decepções. No entanto, o impacto maior será a publicação, na França, do livro $O$ arquipélago do Gulag, (1973). A partir de meados dos anos 70, os intelectuais de esquerda liberam-se de suas últimas ilusões.

No entanto, apesar das decepções em relação ao sistema soviético, os intelectuais de esquerda, nesses tempos de guerra fria, permanecem fiéis ao dogma marxista. Assim, os laços intelectuais mantidos com o PCF, no momento da guerra da Argélia, justificam-se em razão da gravi-

23 Aquele que fala em seu nome e, não mais em nome de um partido ou de um oprimido, e que defende, ocasionalmente, as minorias sexuais e culturais, em nome de uma emancipação do homem.

24 Citado por DREYFUS, H., RABINOW, P. Michel Foucault - un parcours philosophique (trad.), Paris, Gallimard, 1984, p.289. 
dade de uma situação que tendia a instaurar, na França e na Argélia, um "regime de exceção".

Aliás, vale lembrar que a revista Socialismo ou Barbárie(1949), fundada por Claude Lefort e Cornelius Castoriadis, na sua crítica à burocracia stalinista, representa, nesses tempos de "compagnage de route", uma tendência distinta: a de uma esquerda anti-totalitária, se comparada às demais revistas intelectuais da época. No entanto, é somente em meados dos anos 70 que Lefort empreenderá, em conseqüência das revelações do gulag na URSS, as análises sobre o totalitarismo soviético. ${ }^{25} \mathrm{O}$ impacto do livro de Soljenitsyne junto aos intelectuais de esquerda, abre espaços para críticas sobre o significado mesmo de um engajamento intelectual. Os erros cometidos por Jean-Paul Sartre passam, então, a ser medidos em relação às verdades assumidas por Raymond Aron.

A reabilitação de Aron, como intelectual legítimo, coincidindo com a morte de Sartre e de outros "maîtres à penser", assinala o fim de um modelo de representação de intelectual. A partir dos anos 80 , com a "desideologização" das consciências, o vazio deixado pelo abandono do político abre espaços para derivas e auto-críticas por parte dos intelectuais da esquerda. Acusado de ser um "sub-Heidegger" e um "perfeito stalinista", Sartre transforma-se em um verdadeiro "bode expiatório" dos erros, das utopias e das derivas vividas pela intelligentsia francesa.

Fundada nesse mesmo ano (1980), por Pierre Nora e Marcel Gauchet, a revista Le Débat, congratulando-se com o fim do intelectual engajado, milita em favor da democratização do poder intelectual. Isso pressupõe, de imediato, a liberação do intelectual em relação à política e o seu retorno à produção do saber. Nesse final dos chamados "Trinta Gloriosos", as mutações do habitus intelectual, seguidas, portanto dessa crise econômica, que inviabiliza o sentimento do devir, é acompanhada pela redescoberta do pensamento político liberal. A reabilitação de pensadores como Tocqueville, Kant e Rousseau prenunciam a valorização da democracia como centro de reflexão da filosofia política, num momento de enfraquecimento do Estado-nação. Os trabalhos de François Furet sobre a Revolução francesa visam, sem dúvida, a introduzir o pensamento liberal no seio das reflexões políticas..

Se o final do engajamento libera o intelectual de maniqueísmos, reconvertendo- o à sua verdadeira função crítica, o rejeito mesmo de um modelo intelectual, imediatamente seguido pela legitimidade de seu contrário, condicionará, certamente, novos fechamentos. Os anos 80 assistem a passagem de certos valores da esquerda: o altruísmo, por exemplo, tão bem representado pelo "terceiro-mundismo" em direção à prática de novos valores, individualistas e identitários.

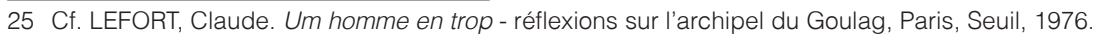


A esse proposito, o livro de Pascal Brückner — Le sanglot de l'homme blanc: Tiers Monde, culpabilité, haine de soi, publicado em 1983, desculpabilizando o ocidente pela existência do Terceiro Mundo, é revelador dessa nova conjuntura intelectual. O retorno ao individualismo, fruto dessa nova era de crises de referência e de sentido, reforça o sentimento de pertencimento a um grupo, a uma nação e a um continente.

Uma década mais tarde, o aceleramento da própria História: as guerras civis nos Bálcãs, os efeitos perversos da globalização sobre as economias nacionais, em outras palavras o declínio mesmo do político, impulsiona um tímido retorno dos intelectuais à cena pública. Evidentemente, não se trata mais de reativar formas antigas de ações, mas de tentar mobilizar a opinião pública em relação aos males que afetam o presente.

Intervindo, na qualidade de experts, algumas figuras intelectuais servem-se da mídia e da ocasião histórica para manifestarem suas indignações e inquietudes. Dois exemplos de situações podem ilustrar essas novas intervenções. O primeiro, durante a guerra dos Bálcãs, marcada pelas violações dos direitos humanos, remete a uma postura ética do papel do intelectual. Bernard-Henry Lévy, se destaca, particularmente, pela sua cruzada em favor da condenação dos crimes de "limpeza étnica", pressionando a União Européia a acionar o Tribunal Penal Internacional. O segundo exemplo: as greves sociais francesas, de dezembro de 1995, revelando o enfraquecimento mesmo do Estado frente ao poderio do econômico, possibilita o retorno da militância intelectual. Inesperadamente, Pierre Bourdieu assume uma postura política, tomando posição junto aos grevistas contra "a destruição de uma civilização" associada à existência do serviço público". ${ }^{26}$ A mundialização das economias, ou seja, a política neo-liberal, praticada pelo governo francês da direita, responsável pelo enfraquecimento da coisa pública, deveria ser, então, combatida por todos os meios.

Ora, se a década dos 80 é marcada pelo "silêncio dos intelectuais", ${ }^{27}$ os anos 90 conhecem uma emergência de situações, ameaçadoras de valores morais e políticos, que justificam o final desse silêncio.

No entanto, curiosamente o pensamento crítico não poupa a própria crítica do intelectual, feita pelos próprios intelectuais, quando se trata de denegrir a sua imagem. A propósito, "o intelectual" sempre constituiu um objeto de polêmica na vida intelectual francesa. Desde a publicação da Trahison des clercs (1927), por Julien Benda, a temática da traição, dos erros e do declínio dos intelectuais tende a provocar debates virulentos, mas também a promover os seus autores. A intervalos regulares, o fim

26 BOURDIEU, Pierre. "Je suis ici pour dire notre soutien ", Libération, 14/12/95.

27 Título de um artigo do historiador e político da esquerda, Max Gallo, publicado, em 1983, no jornal Le Monde. 
dos intelectuais é anunciado, em livros e em panfletos pelos intelectuais. De Jean-François Lyotard à Régis Debray, passando por Pierre Nora, ${ }^{28} \mathrm{O}$ constato da decadência dessa categoria, entendida em termos de sua função política, remete aos contextos atuais de extinção dos valores que haviam determinado o seu aparecimento.

Segundo Régis Debray, a inversão final de todos os valores que marcaram, desde o início, a razão de ser dos intelectuais, seria a responsável pela transformação da imagem, atual, negativa dos mesmos. Em outras palavras, o intelectual parece cristalizar, metamorfoseando-se em bode expiatório, as mutações da conjuntura histórica e intelectual francesa. Sem dúvida, "menos inventiva, menos aberta e menos fecunda", a vida intelectual francesa, a partir da primeira metade dos anos 80, coincidindo com o desaparecimento dos "maîtres à penser", perdeu sua atração e interesse.

Mas, embora o intelectual engajado tenha desaparecido da paisagem intelectual, a marcha irremediável das idéias, fatalmente, reabilita, em algum momento histórico, figuras do pensamento, decretadas ultrapassadas. O exemplo mais notório diz respeito ao renascimento de Sartre, no ano 2000. Vinte anos após o seu desaparecimento, no sentido próprio e figurado do termo, ele retorna, inesperadamente, à cena intelectual francesa. A comemoração do aniversário de sua morte, nesse mesmo ano, dá margens a um número considerável de publicações que, procurando re-atualizar seu pensamento, legitimam o "último intelectual" do século. "Estranha conjuntura para uma tal comemoração póstuma: é nessa passagem ao novo milênio que Sartre, considerado [até pouco tempo] "monumento do passado, datado, criticado, ridicularizado", ressuscita na atualidade como a figura do "intelectual do século".

Em seu livro Le siècle de Sartre, Bernard-Henry Lévy se esforça em mostrar a importância de uma obra que privilegia o indivíduo, a liberdade e a contingência, nesses tempos de inseguranças ontológicas e de incertezas do presente e do futuro. Diante da precariedade de sua própria existência, o indivíduo, confrontado às necessidades do presente, não tenderia a se reportar a alguns temas constitutivos do existencialismo, entre eles o da responsabilidade? 